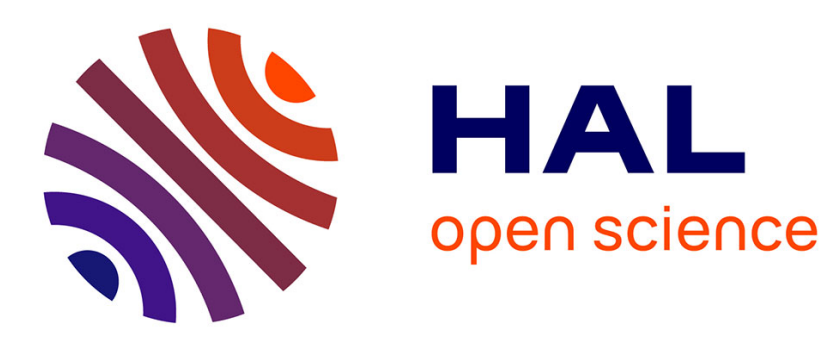

\title{
Deep structural control on distribution of raised beaches and Quaternary sedimentation in Brittany? A review
}

\author{
J. P. Lefort
}

\section{To cite this version:}

J. P. Lefort. Deep structural control on distribution of raised beaches and Quaternary sedimentation in Brittany? A review. Quaternary International, 2011, 231 (1-2), pp.4-9. 10.1016/j.quaint.2010.06.017 . hal-01147560

HAL Id: hal-01147560

https://hal-univ-rennes1.archives-ouvertes.fr/hal-01147560

Submitted on 8 Jul 2020

HAL is a multi-disciplinary open access archive for the deposit and dissemination of scientific research documents, whether they are published or not. The documents may come from teaching and research institutions in France or abroad, or from public or private research centers.
L'archive ouverte pluridisciplinaire HAL, est destinée au dépôt et à la diffusion de documents scientifiques de niveau recherche, publiés ou non, émanant des établissements d'enseignement et de recherche français ou étrangers, des laboratoires publics ou privés. 


\title{
Deep structural control on distribution of raised beaches and Quaternary sedimentation in Brittany? A review
}

\author{
J.P. Lefort* \\ Laboratory of Archéosciences, UMR 6566: CReAAH, University of Rennes 1, Campus of Rennes-Beaulieu, CS74205, 35042 Rennes Cedex, France
}

\begin{abstract}
This paper is a review of the possible influences of deep structures on Quaternary sedimentation and the distribution of raised beaches, a problem which has never been raised before in any paper. The distribution of the Quaternary outcrops is very patchy in Brittany and seems to be organized in a random way, partly because the control by the short wavelength basement structures is not easy to recognize but also because the most efficient control is associated with long wavelength structures which are far beyond the scale of the usual geological maps and the immediate observations. Gravity data and terrain-levelling give far better results than the other geophysical techniques when the Moho undulations are compared with the surficial data. The two main domains involved in the long wavelength deformations are (a) the Alpine domain where all the Moho undulations are concentric with the Alps; and (b) the Armorican domain in which all the undulations are west-northwest-east-southeast oriented, parallel with the axis of the initial opening of the Bay of Biscay.

Study of the topography and of the superficial structures associated with these undulations reveals that the undulations delineated in the Alpine Domain result from compression (buckling). These associated with the Armorican Domain result from extension (boudinage). Both phenomena show a typical wavelength of $200-250 \mathrm{~km}$, which is in agreement with the results of the physical and numerical modeling currently available. These two types of deformations are crosscutting in Brittany.

The general uplift of Western and Central Brittany is a well-controlled geological phenomenon. This is shown by the incision of the rivers which increases towards the west, suggesting larger uplift in the west than in the east. This uplift has been also demonstrated by two different terrain-levelling techniques.

The distribution of the Pleistocene/Holocene sediments is compared with the deep structures. The westernmost Alpine undulation controlled the north-south deposition of the recent loess and swamps in eastern Brittany. The Biscay Bay related structure controlled the deposition of loess along the northern coast of Brittany, and also the location of the Pleistocene raised beaches. The gradient in beach age results from the preferential uplift of the westernmost part of Brittany.
\end{abstract}

\section{Introduction}

The distribution of the Quaternary (Pleistocene and Holocene) outcrops is very patchy in Brittany and Western France. This patchy distribution does not hamper the understanding of the relationships which may exist between the short wavelength crustal discontinuities (faults) and the recent sediment accumulations. However, the lack of horizontal continuity obscures the possible control of the long wavelength crustal phenomena which are, even if often less spectacular, much more important in understanding the reasons for the location, thickness and ages of the patchy outcrops. The deep structures of the crust can be only recognized by

\footnotetext{
* Tel.: +33689780320.

E-mail address: lefort38@yahoo.fr.
}

geophysical prospections. Their study and their comparison with the surface deposits is the best way to decipher if some logic controlled the apparent random distribution of the Pleistocene/ Holocene outcrops which are now located over Brittany. This article describes a few well-documented examples rather than concentrating on the geophysical processing of the data. This article is a review of the data available from deep geophysics and Quaternary stratigraphy. The focus is on the correlations between the surface geology and the structures at depth, rather than on the detailed stratigraphy and the potential field techniques.

\section{Very short wavelength control of sedimentation}

The tectonic control of the very shallow sedimentary deposits at the millimetric or decametric scale is often the indirect result of 
small movements in the basement, or is associated with intraformational water expulsion or with hill slope slumping. Whatever the origin of these deformations, they are, in many cases, affected by a strong superficial pedogenesis which often reworks them. This has been often described for Pleistocene sediments (Van VlietLanoe et al., 1997).

The Pleistocene and Holocene stratigraphy of St Brieuc Bay is now well established along the shore (Monnier, 1973). Fig. 1 shows the correlations which can be established between the two sides of this bay. There is a clear continuity in the colluvium, recent loess, and recent loam all along the section. In the lower part of this section, the continuity between the old loess formation and the presence of old marine beaches is excellent at both ends of this reconstruction but there is a strong disturbance of all the sedimentary horizons in the middle of the section and many gaps in the stratigraphic succession. No interpretation has previously explained the local disturbance of those Pleistocene horizons. The existence of the Quessoy-Vallet shear zone which cut across this zone was not well known at the time when the stratigraphic succession was established. As well, there were no images of the deep crust and of the mantle located under this fault.

The Quessoy-Vallet shear zone is a $130^{\circ}$ crustal disruption which was probably initiated during the Triassic (Lefort, 1973), and rejuvenated during the Cenozoic (Jeager, 1967). Its present activity is demonstrated by the linear succession of seismic epicenters which follow it. At a first glance, this basement fault zone can be considered as a short wavelength disruption affecting the upper crust and controlling only the Quaternary sedimentation. However, it corresponds to a main lithospheric deep-seated fault zone which separates two different crusts characterized by two different velocities. This break (Fig. 2) is well expressed between 60 and $95 \mathrm{~km}$ depth and between 130 and $200 \mathrm{~km}$ depth (Judenherc et al., 2003). As this shear zone was affected by dextral transcurrent displacements, and because in northern Brittany, loess were trapped unequally as a function of wind directions (Bigot, 1986), topography and moisture (Monnier, 1973), the two parts of the section now display, side by side, sedimentary horizons which were not necessarily of an equivalent thickness during their initial deposition. This abrupt contact is probably not the result of a single fault activity but more probably the consequence of the accumulation of many successive disruptions, as the disturbed zone is several kilometres in width at the surface.

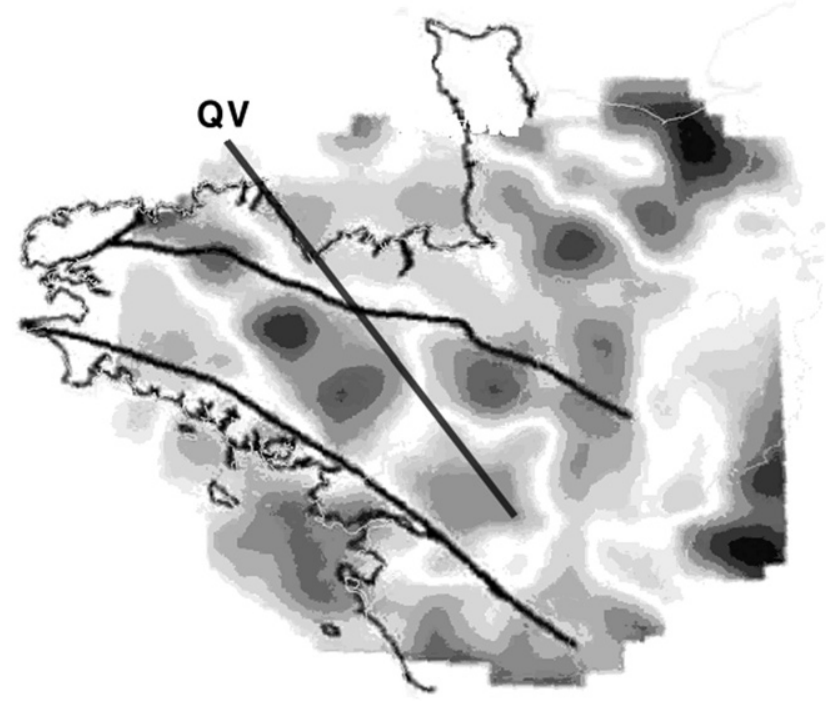

Fig. 2. Tomographic image of the crust at the level of the Quessoy-Vallet fault zone (after Judenherc et al., 2003). Darker color corresponds with higher lithospheric velocities. QV: Quessoy-Vallet fault.

\section{Long wavelength control of the Pleistocene/Holocene sedimentation in Brittany}

The mapping of the long wavelength crustal undulations in France has been presented elsewhere. It is mainly based on a comparison between the gravity and the topographic data (Lefort and Agarwal, 2000, 2002). For this purpose, the complete gravity dataset from France and part of the neighboring countries was analyzed to compute the topography of the Moho undulations (Fig. 3). This work was based on an improved filtering technique and an appropriate assumed density contrast between the crust and the upper mantle. Comparison with deep seismic refraction data reveals that this relief map expresses the continuity and geometry of the Moho undulations better than the sparsely distributed seismic refraction data. Four domains have been recognized: the Alpine domain, the Armorican domain, the Pyrenean domain, and the Massif Central domain. At the scale of the

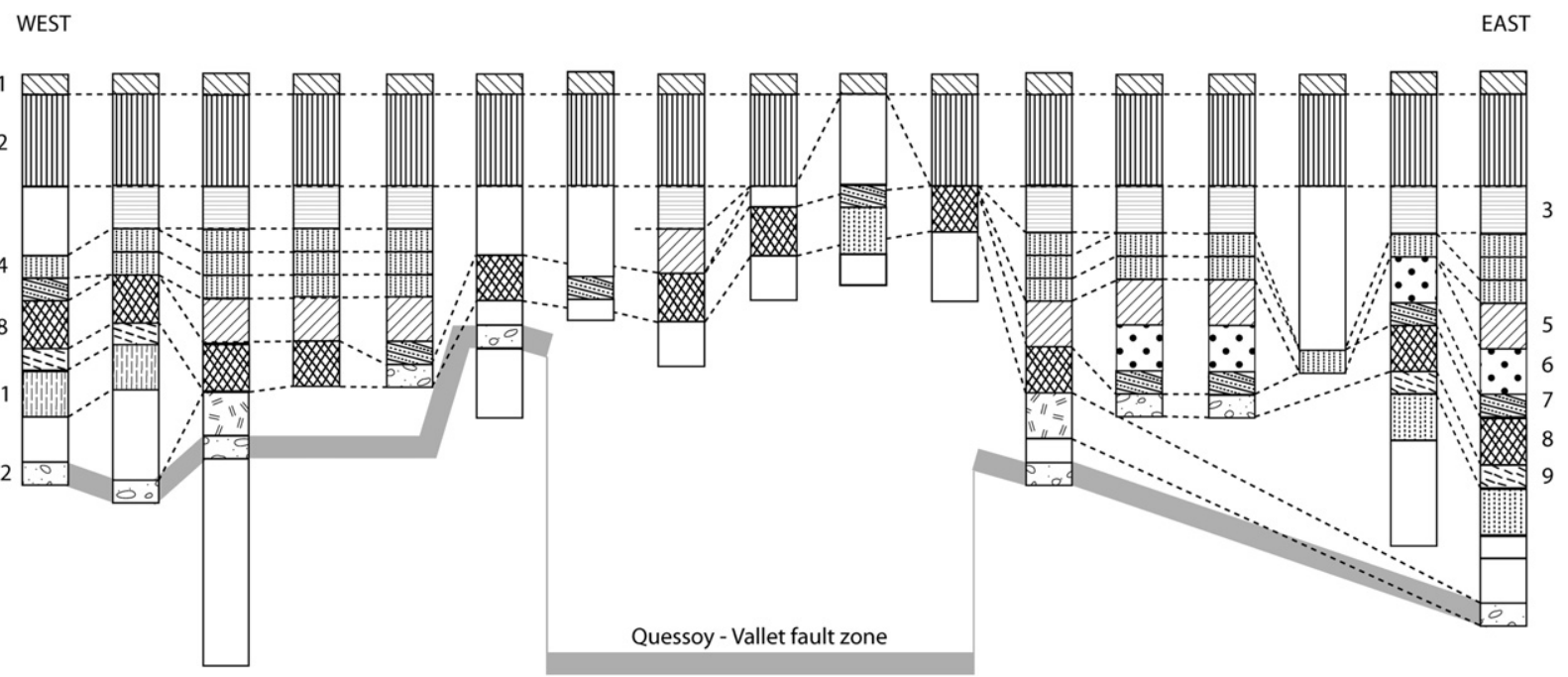

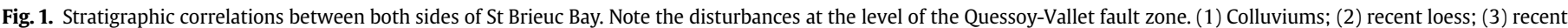

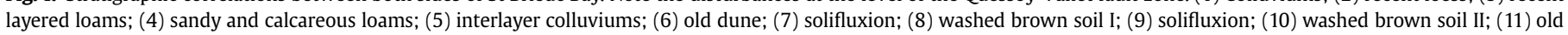
loess; and (12) fossil beach (redrawn and completed after Monnier, 1973). 


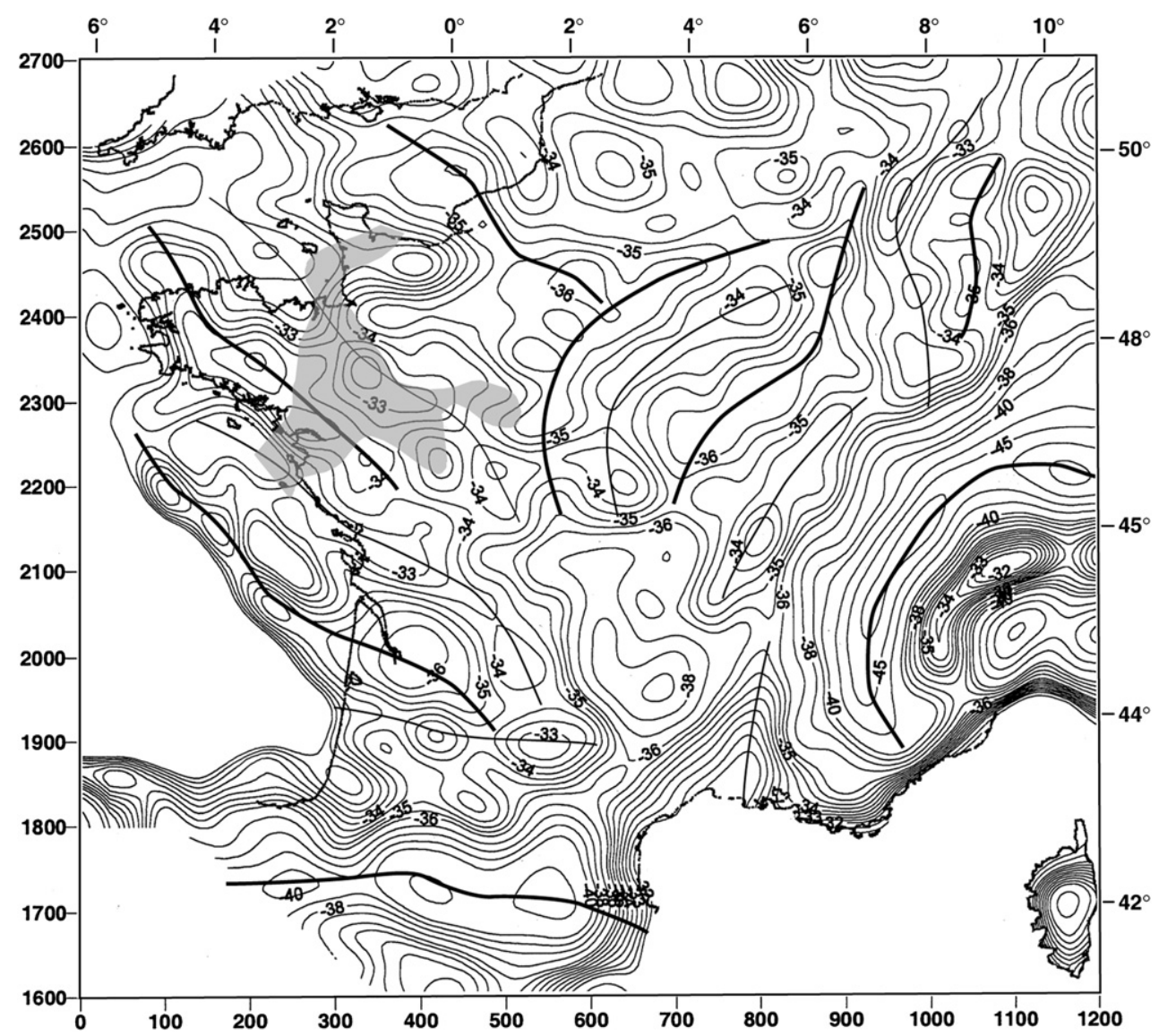

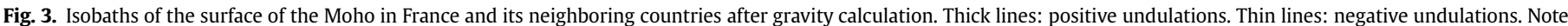
the gray zone corresponding with the Miocene marine transgression. Depths are expressed in kilometer (after Lefort and Agarwal, 2002).

whole French territory, the two most developed and interesting domains are the Alpine and the West Armorican domains. As Brittany is the only area affected by these two long wavelength deformations, the other results will be ignored in this paper.

Two types of periodic crustal instabilities have been recognized when the Moho undulations and the topography are compared. The first corresponds with the buckling of the crust developed under compression. The second corresponds with boudinage which is associated with extension (Lefort and Agarwal, 2000). Both phenomena show a typical wavelength of $200-250 \mathrm{~km}$, which is in agreement with the results of the actual physical and numerical modeling currently available.

\subsection{Contribution of the long wavelength Alpine deformations to the control of the Pleistocene/Holocene sedimentation in Eastern Brittany}

The Alpine domain is characterized by Moho undulations which are concentric with the Alps (Fig. 3). Study of the superficial structures associated with these undulations reveals that the Alpine Domain is the result of the Palaeogene to Quaternary compressions associated with the formation of the Alps (Lefort and Agarwal, 2002). Study of the sediments deposited in the depressions generated by these undulations shows that the undulations delineated in this domain are still active. The westernmost undulation has been delineated with difficulty because the processing technique is limited when the amplitude of the Moho undulations are smaller than $3 \mathrm{~km}$. Delineation was controlled by seismic refraction data which have good density in this area (Fig. 4). The arched and shallow gully running between Normandy and Brittany at $2^{\circ} \mathrm{W}$ was used by the Miocene transgression (see the gray pattern on Fig. 3). Nowadays this large gully still behaves as a subsiding zone. It is mainly active at its northeastern end, since negative vertical movements ranging between -0.4 and $-0.2 \mathrm{~mm} / \mathrm{y}$ (Lenotre et al., 1999) have been recorded in this area. The delineated gully encompasses successively, from north to south, the Carentan and Bessin marshes in Cotentin, the Bay of Mont St Michel, the Dol marsh, the Rennes Basin, the Redon marsh and the lowlands associated with the mouth of the Loire River (Fig. 5).

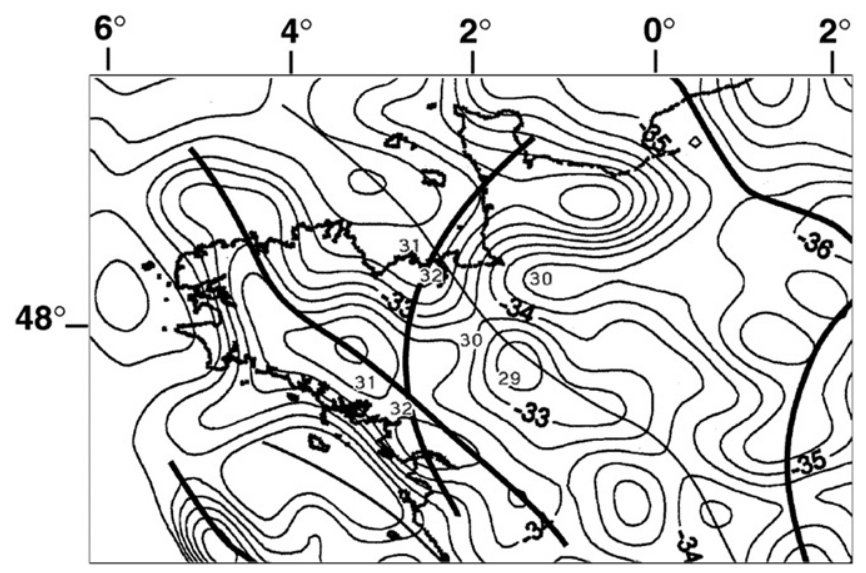

Fig. 4. Location of the Moho undulations beneath Brittany. Depths are expressed in kilometer. Random gray numbers: depths after seismic refraction data. Thick lines: undulations axis. 


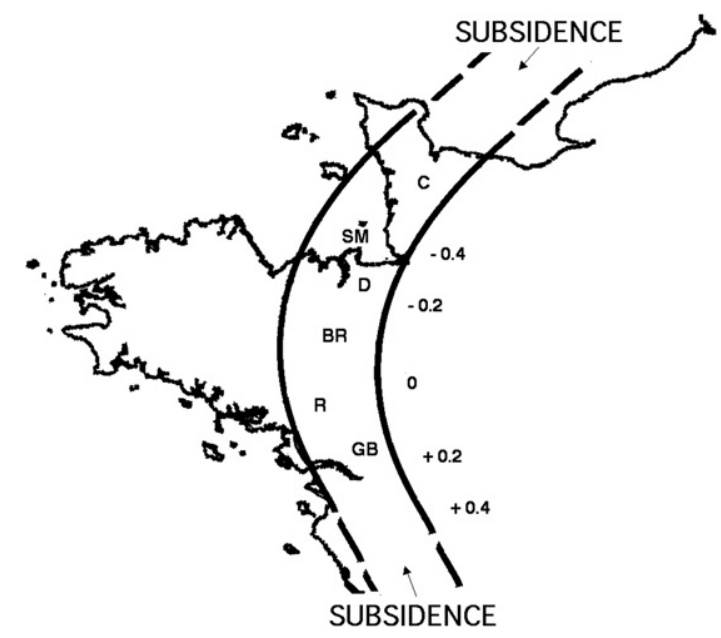

Fig. 5. Location of the swamps in Eastern Brittany. C: Carantan swamp; SM: MT St Michel Bay; D: Dol swamp; BR: Rennes Basin; R: Redon swamp; and GB: Grande Briere swamp. The present day measured vertical movements are given on the right side in millimeter/year (after Lenotre et al., 1999).

In the Carentan marshes and neighboring areas, the Lower Pleistocene is well developed and preserved. After the PliocenePleistocene regression, nearshore shelly, marly and sandy deposits dominated (Dugué, 2003). The Bay of Mont St Michel shows only remnants of old terraces of Saalian age, and most of the sediments are Weischelian and characterized by sands, head, gravels, loams and loess on reliefs. The Eemian beaches were eroded at the end of the Weischelian. During the Holocene, many thick layers of fine sediments were deposited at the same time as the development of peat formations (Lautridou et al., 1995). The evolution of the Dol marsh is identical to those of Netherlands with sand, silt and peat alternations, resting directly on the basement (Morzadec-Kerfourn, 1995). In Briere, at the mouth of the Loire River, the Pleistocene is poorly known and probably partly eroded. Most of the marsh is filled by Holocene blue mud and a brown peat overlain by a black turf (Visset, 1990). Between the two, the Redon marshes and Rennes basin are less well documented but are mainly filled by Holocene sediments.

Taken as a whole, this arcuate and wet zone is filled by limited Pleistocene deposits which are partly eroded. Most of the swamps are filled by Holocene sediments.

The existence of loess deposits associated with the same arched structure must be emphasized, as the presence of loess in the central part of Eastern Brittany and Northern Vendée has never been really explained, loess being usually supposed to be restricted to the northern coast of Brittany. The clear superimposition which can be observed between the north-south oriented recent loess outcrops (Fig. 6) and the subsided gully previously described (Fig. 5), provides an explanation for this anomaly, considering that loess dust needs some moisture to be fixed and stabilized (Monnier, 1973). Although the swamps were probably frozen during part of the Upper Pleistocene, there have been also warmer periods when they were wet enough to trap the loess dust. Furthermore, the transportation of this dust by the northwest to north winds (Bigot, 1986) was easier in this subsided area devoided of any topographic highs, in contrast to the relief which exists in the west and east, and which behaved as a continuous barrier for the dispersion of loess in southern Brittany.

\subsection{Biscay Bay related West-Northwest-East-Southeast long wavelength deformations and sedimentation in Brittany}

The main crustal positive undulation which forms the axis of the West Armorican Domain (Figs. 3 and 4) developed as a reaction to an extensional phenomenon (boudinage) associated with the Lower to Middle Cretaceous opening of the Bay of Biscay (Lefort and Agarwal, 2000). However, the present behaviour of this positive topographic ridge can be only understood if it is related to the Palaeogene to Quaternary closure of the bay. The consequence of this closure is that Brittany is actually affected by a strong isostatic disequilibrium, as the calculated root lying under Brittany is far too large when compared with its topography (Lefort and Agarwal, 2000). This is the reason why western Brittany is undergoing uplift. This has been confirmed by various terrrain-levelling surveys (Lenotre et al., 1999) and by the study of the indentation of the rivers (Bonnet, 1998).

Central Brittany is almost devoid of recent Quaternary sediments. During Pleistocene times it was affected by periglacial phenomena, and few things are known with certitude because of insufficient study. Along the topographic highs, coarse detrital sediments were deposited as unconsolidated conglomerates with no relationship with the paleovalleys (Lebret et al. 1997 in Andreieff, 1997). On the slopes of the valleys, terraces are observed but their age is usually unknown, save along the Vilaine river where they are considered as Cromerian in age (Monnier et al., 1981).

The best evidence for the control of the uplift on the sedimentation is given by the distribution of the recent loess formations. It is known that loess formations are mainly developed on the northern coast of Brittany (Basse de Menorval and Théobald, 1974). This preferential development occurs for three different reasons: (1) the North to Northwest origin of the dust (Bigot, 1986); (2) the presence of cliffs which acted as dust traps; and (3) the existence of moisture able to fix the dust particles (Monnier, 1973). It is only because of the presence of the central uplifted ridge that the northern shore is bounded by cliffs which are now coated by thick loess formations, and why loess does not exist south of Brittany.

\subsection{Interaction between the Alpine and Biscay Bay related long wavelength Moho undulations and control on sedimentation in Brittany}

Brittany is a particularly interesting area to check the reality of the control on sedimentation, as it lies at the intersection between two different types of crustal deformations. Comparison between Figs. 4 and 6 is very informative from this point of view. Fig. 6 shows that the late Pleistocene loessic dust only crossed Brittany where the westernmost Alpine gully developed. In contrast, south of this gully where the two types of deformations are superimposed there are no loess deposits (see the star on Fig. 6). Nowadays, in this particular area, the subsidence rate is zero (Lenotre et al., 1999).

\section{Long wavelength control of the raised beaches in Brittany}

Compilation of the ages of the Pleistocene raised beaches and lower cliff material (Van Vliet-Lanoe et al., 1997) as well as those inferred from stratigraphic studies (Monnier, 1973) have been compared with the ages of the submerged beaches studied in the English Channel (Danukalova and Lefort, 2009). Taken as a whole, the distribution of those remnants of the previous Upper Pleistocene shores appears to be random and unorganized (Fig. 7). However, separate analysis of the submarine data and onshore data, and the results from western and eastern Brittany reveals interesting results.

Offshore, the Pleistocene formations are now known to be the result of a continuous regressive episode (even if affected by some second order oscillations), leading to a complete exposure of the English Channel. The former beaches, which now appear as a conglomerate consisting of marine shells and cobbles, were consolidated during four different stable stages of regression of the 


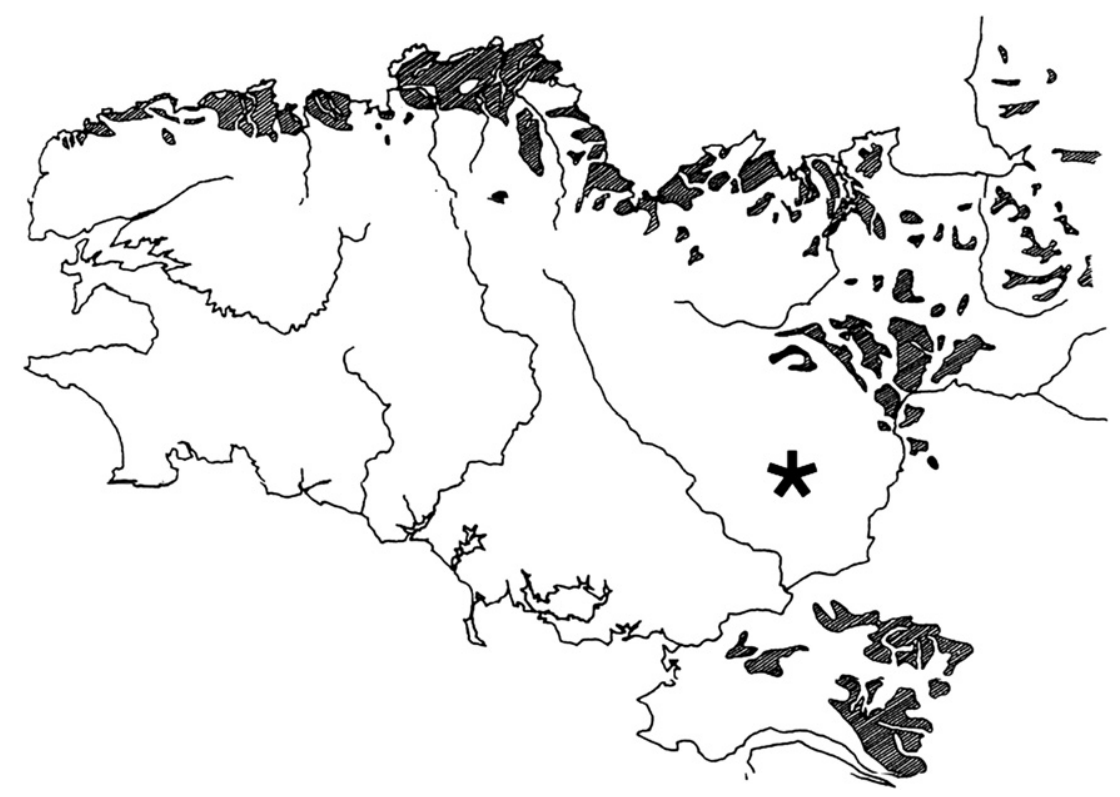

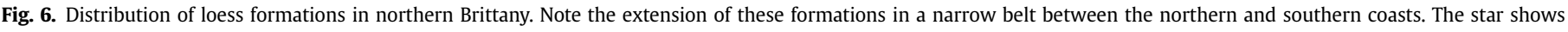
where the uplifting and subsiding zones are crosscutting.

sea under various loess covers. Their ages range between 120 and $18 \mathrm{ka}$ (MIS 5c-d and MIS 3). Younger ages observed towards the west are thus easily explainable by the evolution of the English Channel.

Onshore, and save in two localities, there is a clear younging of the ages of the raised beaches from west to east, ranging from MIS 5 (and even MIS 2) in the east to MIS 13 in the west. It is very likely that this is related with the differential uplift of Brittany. Fig. 7 shows how the uplift axis (U on Fig. 7) obliquely cuts the subsiding zone (S on Fig. 7). This explains the complexity of the distribution in ages. There is an excellent coherency between the age of the raised beaches and the uplift and subsiding zones: the higher the uplift rate, the older the raised beaches. All the recent raised beaches are located at the level of the subsiding zone. The basement was more or less stable in the intermediate area, as shown by the intermediate MIS ages (Fig. 8). The uplift and subsiding phenomena are completely independent of each other. The former is of isostatic origin, and the second is related with the Alpine buckling of the crust. The isostatic uplift phenomenon and the buckling of the lithosphere are long and slow processes which cannot stop or restart rapidly. It is not known if more recent Pleistocene raised beaches were ever deposited in the West and were later eroded. This is theoritically possible since MIS 11 and 9 sea levels reached almost the same altitude as during MIS 13

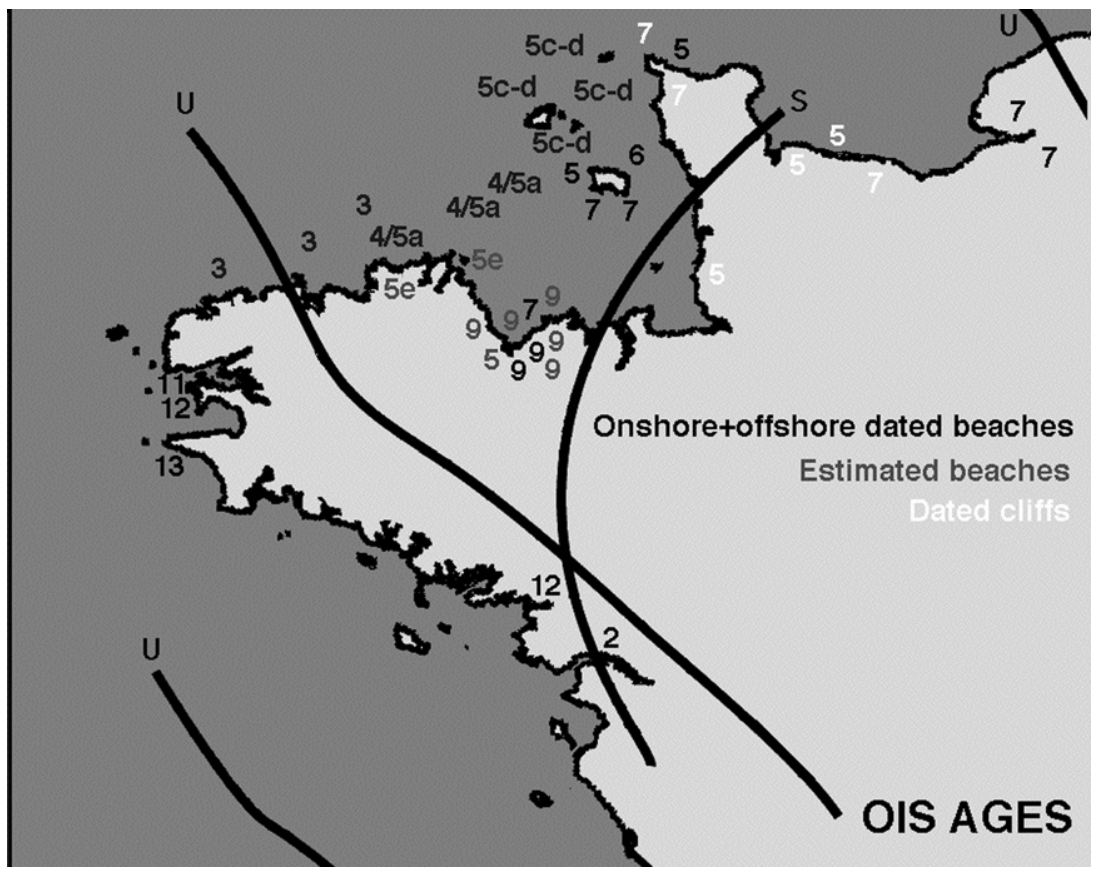

Fig. 7. Location of the offshore and onshore raised beaches and associated formations. The ages are given after the MIS scale. 


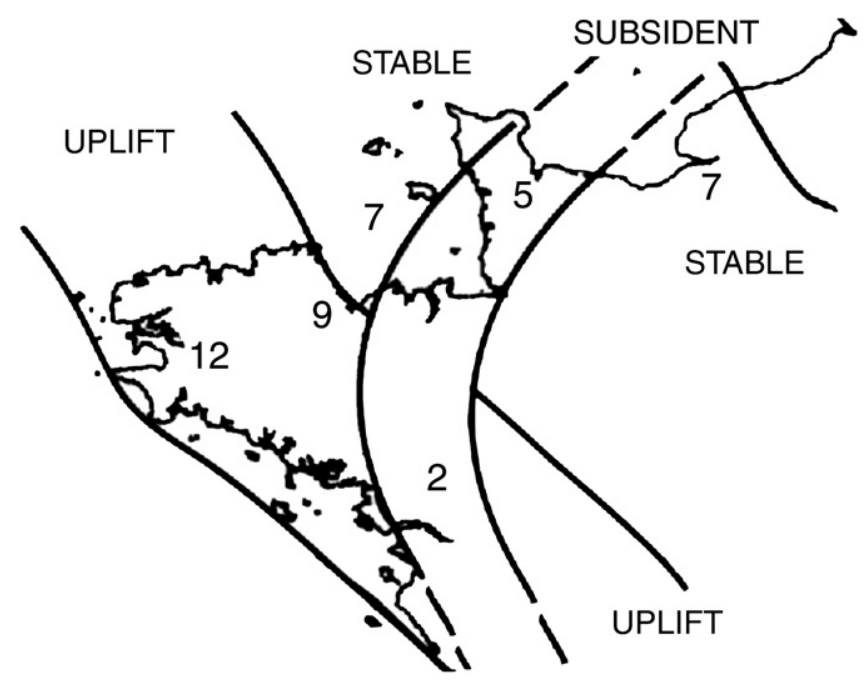

Fig. 8. Mean ages of the raised beaches (calculated by zone).

(Van Vliet-Lanoe et al., 1997). However, sediments of those ages may never have been deposited on the oldest raised beach because of the slow but real uplift previously described.

\section{Conclusion}

The variations in the location, thickness and nature of the sediments deposited in Brittany during Pleistocene and Holocene times have been partly controlled by two different types of basement deformations. These deformations were all associated with long wavelength crustal disturbances even if they sometimes appear to be related with short wavelength accidents at the surface.

The clear relationship which exists between the distribution of the Pleistocene and Holocene sedimentations (which are usually of limited thickness) and the long wavelength Moho undulations was previously ignored. Those parameters should be considered when stratigraphic discrepancies are observed between the Atlantic and continental Europe since the effect of the Alpine and Biscay Bay controls on the sedimentatation are relatively local features at the scale of Europe.

During the Upper Pleistocene, the larger uplift which developed in westernmost Brittany preserved the oldest raised beaches known in the area. In contrast, the subsiding zone preserved the youngest sediments and raised beaches known in eastern Brittany. Because of the interaction between the two crustal processes, loess is missing where they are crosscutting.

There has been also a clear competition between the WestNorthwest-East-Southeast uplift which affected the onshore zones and the offshore sedimentation which was associated with the general regression of the English Channel. The topographic uplift which was probably rising more or less at the same rate during the Upper Pleistocene (and which is now $0.8 \mathrm{~mm} / \mathrm{y}$ close to the uplift axis) was not sufficient to disturb the deposition of the offshore sediments associated with the regression of the English Channel.

Calculation of the mean regressive velocity of the English Channel between $120 \mathrm{ka}$ and $20 \mathrm{ka}$ shows that this velocity was around $1.2 \mathrm{~mm} / \mathrm{y}$, much higher than the onshore uplift velocity. This is the reason why there are no recent raised beaches in the northwestern part of Brittany. In the subsiding area the subsiding rate has never been sufficient to accumulate younger marine deposits when the sea was not adjacent.

\section{Acknowledgements}

Many thanks must be addressed to J.L. Monnier and D. Margerie of the Laboratory of Archeosciences of the University of Rennes 1, France, for welcoming me at UMR 6566 (CReAAH) and their assistance during the last 3 years.

\section{References}

Andreieff, P., 1997. Notes d'orientation pour l'établissement de la carte géologique de France au 1/500000. Documents du BRM. BRM, 255 pp.

Basse de Menorval, E., Théobald, N., 1974. Carte géologique du Quaternaire et des formations superficielles de la France au 1:1000000, Besançon. Annales scientifiques de l'Université de Besançon.

Bigot, B., 1986. Essai de modèlisation de l'apport loessique en Bretagne (France). Compte Rendus de l'Académie des Sciences, Paris, Series II 303 (10), 919-921.

Bonnet S., 1998. Tectonique et dynamique du relief: Le socle Armoricain au Pléistocène. Thesis, University of Rennes $1,352 \mathrm{pp}$.

Dugué, O., 2003. The Pliocene to Early Pleistocene marine to fluviatile succession of the Seuil du Cotentin basins (Armorican Massif, Normandy, France). Journal of Quaternary Science 18, 215-226.

Jeager, J.L., 1967. Un alignement d'anomalies légères coincidant avec des bassins tertiaires en Bretagne. Mémoire du B.R.G.M. 52, 89-102.

Judenherc, S., Granet, M., Brun, J.P., Poupinet, G., 2003. The Hercynian collision in the Armorican Massif: evidence of different lithospheric domains inferred from tomography and anisotropy. Bulletin de la societé Géologique de France 174, 45-57.

Lautridou, J.P., Clet-Pellerin, M., Morzadec-Kerfourn, M.T., 1995. Evolution de la Baie du Mt St Michel: Pleistocene et Holocene. Baie du Mt St Michel et Marais de Dol. Centre Régional d'Archéologie d'Alet, pp. 28-32.

Lefort, J.P., 1973. La zonale Biscay-Labrador, mise en évidence de cisaillements dextres antérieurs à l'ouverture de l'Atlantique Nord. Marine Geology 14, 33-38.

Lefort, J.P., Agarwal, B.N.P., 2000. Gravity and geomorphological evidence for a large crustal bulge cutting across Brittany (France): a tectonic response to the closure of the Bay of Biscay. Tectonophysics 323, 149-162.

Lefort, J.P., Agarwal, B.N.P., 2002. Topography of the Moho undulations in France from gravity data: their age and origin. Amsterdam. Tectonophysics 350, 193-213.

Lenotre, N., Thierry, P., Blanchin, R., Brochard, G., 1999. Current vertical movement demonstrated by comparative levelling in Brittany (northwest France). Tectonophysics 301, 333-344.

Monnier J.L., 1973. Contribution à l'étude des dépôts quaternaires de la région de Saint Brieuc. Thesis, University of Rennes 1, 260 pp.

Monnier, J.L., Jumel, G., Jumel, A., 1981. Le Paleolithique inférieur de la cote 42 à St Malo de Phily (Ile et Vilaine): stratigraphie et industrie. Bulletin de la societé Géologique de, France 72, 317-342.

Morzadec-Kerfourn, M.T., 1995. Le marais maritime de Dol-de-Bretagne et le remplissage Holocene: Baie du Mt St Michel et Marais de Dol. Centre Régional d'Archéologie d'Alet, pp. 33-45.

Van Vliet-Lanoe, B., Hallegouet, B., Monnier, J.L., 1997. The Quaternary of Brittany. Revue Archéologique de l'Ouest, 117.

Visset, L., 1990. 8000 ans en Brière. Ouest France, 30. 